\title{
Stable isotope values in modern bryozoan carbonate from New Zealand and implications for paleoenvironmental interpretation
}

\author{
ABIGAIL M. SMITH \\ Department of Marine Science \\ University of Otago \\ P.O. Box 56 \\ Dunedin, New Zealand \\ email: abby.smith@stonebow.otago.ac.nz
}

\section{CAMPBELL S. NELSON}

Department of Earth Sciences

University of Waikato

Private Bag 3105

Hamilton, New Zealand

\section{MARCUS M. KEY, Jr}

Department of Geology

Dickinson College

P.O. Box 1773

Carlisle, PA 17013, USA

\section{WILLIAM P. PATTERSON}

Department of Geological Sciences

University of Saskatchewan

114 Science Place

Saskatoon, SK S7N 5E2, Canada

\begin{abstract}
Bryozoan carbonate contains useful geochemical evidence of temperate shelf paleoenvironments. Stable isotope values were determined for 103 modern marine bryozoan skeletons representing 30 species from New Zealand. $\delta^{18} \mathrm{O}$ values range from -1.4 to $2.8 \%$ VPDB, while $\delta^{13} \mathrm{C}$ range from -4.5 to $2.8 \%$ V VPDB (values uncorrected for mineralogical variation). These values are distinct from those of both tropical marine skeletons and New Zealand Tertiary fossils. Most bryozoans secrete carbonate in or near isotopic equilibrium with sea water, except for Celleporina and Steginoporella. The complex and variable mineralogies of the bryozoans reported here make correction for mineralogical effects problematic. Nevertheless, mainly aragonitic forms display higher isotope values, as anticipated. Both temperature and salinity constrain $\delta^{18} \mathrm{O}$ and $\delta^{13} \mathrm{C}$ values, and vary with latitude and water depth. Ten samples from a single branch of Cinctipora elegans from the Otago shelf cover a narrow range, although the striking difference in carbon isotope values between the endozone and exozone probably reflects different mineralisation histories. Our stable isotope results from three different laboratories on a single population from a single location are encouragingly
\end{abstract}

G03060; Online publication date 1 December 2004 Received 12 June 2003; accepted 23 February 2004 consistent. Monomineralic bryozoans, when carefully chosen to avoid species suspected of vital fractionation, have considerable potential as geochemical paleoenvironmental indicators, particularly in temperate marine environments where bryozoans are dominant sediment producers.

Keywords bryozoans; carbonate; oxygen isotopes; carbon isotopes; New Zealand shelf

\section{INTRODUCTION}

Marine organisms precipitate carbonate skeletons by extracting ions from sea water. The resulting skeletal material records geochemical information that can be related to the environment of precipitation. Stable oxygen and carbon isotope values have proved particularly useful for paleothermometry and paleoenvironmental reconstruction (e.g., Anderson 1990; Corfield 1995). Stable isotope studies have generally focused on foraminifera and invertebrates such as brachiopods which have been shown to precipitate skeletal carbonate in isotopic equilibrium with ambient sea water. Stable isotope paleothermometry has been used in both modern and ancient tropical settings (e.g., Corfield 1995) and, to a lesser extent, in temperate carbonates (e.g., Rao \& Nelson 1992; Bone \& James 1997; Goodwin et al. 2001).

Carbonate sediments on austral temperate shelves are dominated by skeletal remains of bryozoans and molluscs (Rao 1996). These "bryomol" skeletal carbonates stretch for $>4000 \mathrm{~km}$ along the southern Australian shelf (James 1997), and the New Zealand shelf is blanketed with some $56000 \mathrm{~km}^{2}$ of carbonate deposits that consist of $30-90 \%$ bryozoan material (Nelson et al. 1988a). Cenozoic analogues crop out onshore, with particularly extensive cool-water bryozoan limestones in the mid-Tertiary of both Australia (e.g., James \& Bone 1989, 1991, 1994) and New Zealand (Nelson 1978; Nelson et al. 1988b). There are nearly 1000 bryozoan species in New Zealand (Nelson \& Gordon 1997), but only a few large erect shelf species (e.g., Cinctipora elegans, Celleporaria agglutinans, Hippomenella vellicata, Adeonellopsis spp., and Hornera spp.) are responsible for most carbonate sediment formation. Large colonies may produce up to $200 \mathrm{~g}$ carbonate over the course of a colonial lifespan of some $20 \mathrm{yr}$ (Smith et al. 2001).

Stable isotope values in bryozoan carbonate are proving to be useful in a variety of applications as it seems that most bryozoans precipitate carbonate in isotopic equilibrium with sea water (Forester et al. 1973; Bone \& James 1997; Rahimpour-Bonab et al. 1997a; Crowley \& Taylor 2000), apparently free of the vital effects which render, for example, echinoderms unreliable for paleoenvironmental analysis (Weber \& Raup 1966). Stable isotope profiles within single colonies have been used to determine age and growth rate in several species (Pätzold et al. 1987; Brey et al. 1999; Bader 2000). Paleoenvironmental studies also have used 


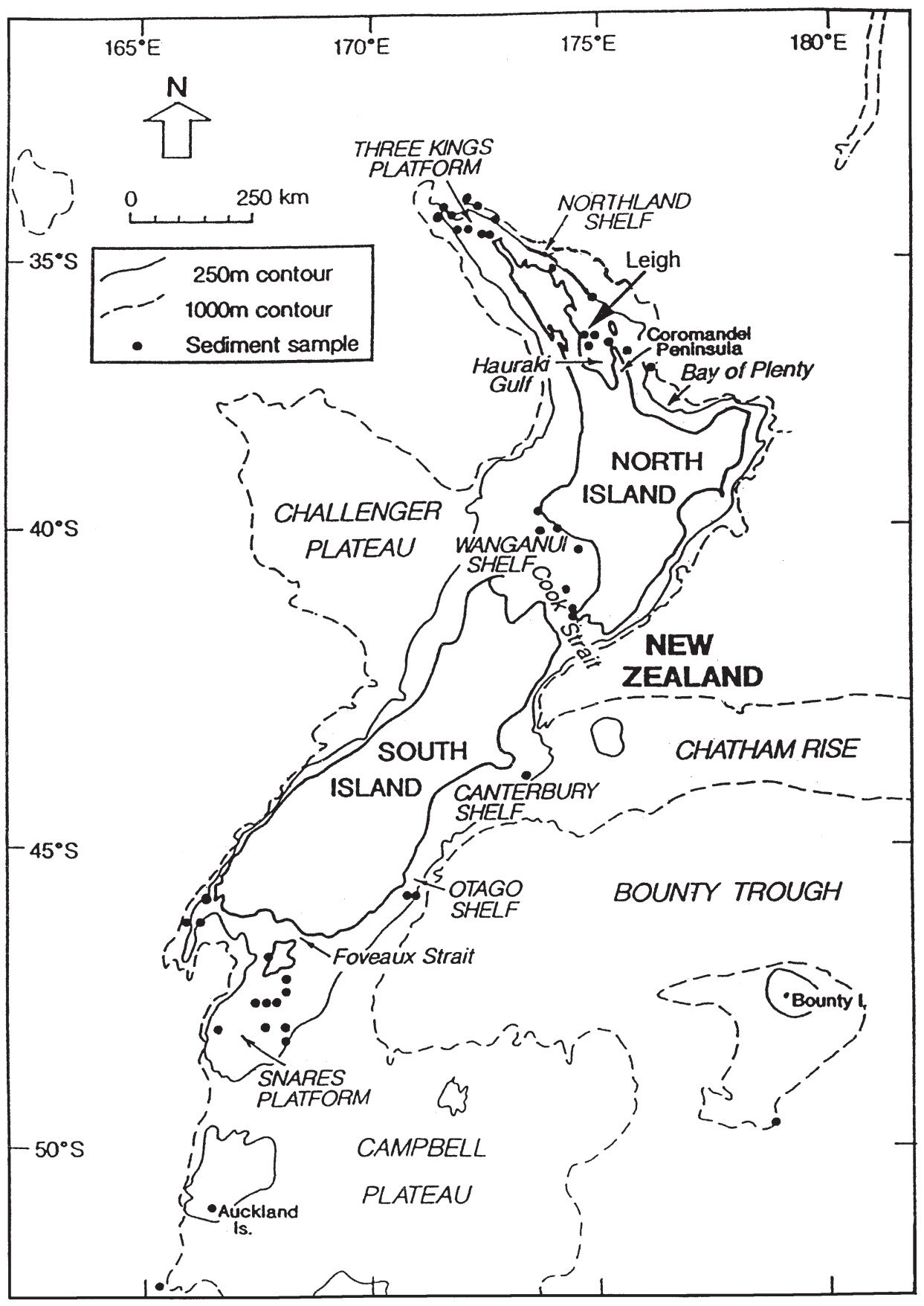

Fig. 1 Sample locations for 103 specimens of extant bryozoans from New Zealand (see Table 1).

stable isotope values of bryozoans for paleoecological and paleoclimatic reconstructions (e.g., Taviani et al. 1993; Nelson \& Smith 1996; Rao 1996; Rahimpour-Bonab et al. 1997b; Smith \& Key 2004).

We present oxygen and carbon stable isotopic data from modern New Zealand bryozoans, taking a species approach in order to evaluate their utility for paleoenvironmental analysis. We compare our data with other published work on New Zealand and Australian bryozoans, most of which group species together in taxa or growth form categories, and we discuss correlation of bryozoan stable isotopic geochemistry with environment.

\section{METHODS}

Ninety-three specimens comprising 30 species of sedimentforming bryozoans from 33 different sample locations were selected for analysis, with a further 10 samples from a single specimen (see below). Sediment samples were collected by grab sampler or dredge from areas of carbonate accumulation on the New Zealand shelf and adjacent subantarctic islands. They ranged in latitude from 34 to $52^{\circ} \mathrm{S}$, and water depths ranged from 8 to $292 \mathrm{~m}$ (Table 1; Fig. 1; see also Smith \& Nelson 1993). Clean, unaltered specimens were selected under a binocular microscope, washed in distilled water, 
Table 1 Stable isotopes in skeletons of New Zealand bryozoans. Sample locations from Smith \& Nelson (1993) (Waikato data), with the exception of samples QQ from the Otago shelf which comprise a series of measurements along a single branch of Cinctipora elegans (Syracuse data).

\begin{tabular}{|c|c|c|c|c|c|c|c|c|c|c|}
\hline \multicolumn{4}{|c|}{ Sample locations } & \multicolumn{5}{|c|}{ Bryozoan species } & \multicolumn{2}{|c|}{ Stable isotopes } \\
\hline $\begin{array}{l}\text { Sample } \\
\text { location }\end{array}$ & $\begin{array}{l}\text { Latitude } \\
\left({ }^{\circ} \mathrm{S}\right)\end{array}$ & $\begin{array}{c}\text { Longitude } \\
\left({ }^{\circ} \mathrm{E}\right)\end{array}$ & $\begin{array}{c}\text { Water } \\
\text { depth }(\mathrm{m})\end{array}$ & Genus & Species & Taxon* & $\begin{array}{l}\text { Growth } \\
\text { form }^{\dagger}\end{array}$ & $\begin{array}{l}\text { Carbonate } \\
\text { mineralogy }\end{array}$ & $\begin{array}{c}(\mathrm{mg} / \mathrm{g}) \\
\delta^{18} \mathrm{O}\end{array}$ & $\begin{array}{c}\text { VPDB } \\
\delta^{13} \mathrm{C}\end{array}$ \\
\hline D114 & 44.20 & 173.30 & 84 & Adeonellopsis & sp. & $\mathrm{CH}$ as & ERro & $\mathrm{A} /(\mathrm{IMC})$ & 1.82 & 2.19 \\
\hline D38 & 51.97 & 165.47 & 252 & Adeonellopsis & sp. & & & & 2.72 & 2.49 \\
\hline D44 & 47.50 & 168.01 & 120 & Adeonellopsis & sp. & & & & 2.26 & 2.73 \\
\hline E26 & 47.68 & 167.40 & 144 & Adeonellopsis & sp. & & & & 2.35 & 2.68 \\
\hline E820 & 46.58 & 165.97 & 220 & Adeonellopsis & sp. & & & & 1.97 & 2.18 \\
\hline P609 & 40.01 & 174.08 & 75 & Adeonellopsis & sp. & & & & 0.89 & 2.45 \\
\hline P448 & 34.39 & 172.47 & 101 & Annectocyma & $\mathrm{sp}$. & CY tu & ERro & LMC & 0.89 & 0.96 \\
\hline P614 & 40.17 & 174.58 & 90 & Annectocyma & $\mathrm{sp}$ & & & & 0.06 & 0.89 \\
\hline C12 & 36.49 & 175.38 & 53 & Arachnopusia & unicornis & $\mathrm{CH}$ as & ENul & $\mathrm{IMC} /(\mathrm{A})$ & 0.48 & 0.34 \\
\hline L21 & 36.08 & 175.04 & 71 & Arachnopusia & unicornis & & & & 1.19 & 0.83 \\
\hline L33 & 36.17 & 174.83 & 58 & Arachnopusia & unicornis & & & & 0.92 & 0.58 \\
\hline P609 & 40.01 & 174.08 & 75 & Arachnopusia & unicornis & & & & -0.47 & 0.77 \\
\hline $\mathrm{C} 12$ & 36.49 & 175.38 & 53 & Cellaria & immersa & $\mathrm{CH}$ an & EFbr & LMC/IMC & 0.66 & 1.04 \\
\hline E26 & 47.68 & 167.40 & 144 & Cellaria & immersa & & & & 1.58 & 1.58 \\
\hline E27 & 47.67 & 167.65 & 131 & Cellaria & immersa & & & & 1.84 & 1.66 \\
\hline E820 & 46.58 & 165.97 & 220 & Cellaria & immersa & & & & 1.84 & 1.56 \\
\hline P448 & 34.39 & 172.47 & 101 & Cellaria & immersa & & & & 1.24 & 1.35 \\
\hline P454 & 34.25 & 172.16 & 292 & Cellaria & immersa & & & & 2.37 & 1.57 \\
\hline P614 & 40.17 & 174.58 & 90 & Cellaria & immersa & & & & 0.40 & 1.23 \\
\hline B488 & 46.50 & 166.24 & 164 & Celleporaria & agglutinans & $\mathrm{CH}$ as & ENml & IMC & 1.30 & 0.83 \\
\hline $\mathrm{C} 12$ & 36.49 & 175.38 & 53 & Celleporaria & agglutinans & & & & 0.74 & 0.67 \\
\hline LF & 36.27 & 174.80 & 8 & Celleporaria & agglutinans & & & & 0.25 & 0.00 \\
\hline P609 & 40.01 & 174.08 & 75 & Celleporaria & agglutinans & & & & 0.04 & 1.00 \\
\hline P454 & 34.25 & 172.16 & 292 & Celleporina & costazii & $\mathrm{CH}$ as & ENnd & $\mathrm{IMC} /(\mathrm{A})$ & 2.26 & 1.68 \\
\hline P558 & 33.98 & 171.72 & 178 & Celleporina & costazii & & & & 1.68 & 1.74 \\
\hline P609 & 40.01 & 174.08 & 75 & Celleporina & costazii & & & & 0.29 & 1.55 \\
\hline P614 & 40.17 & 174.58 & 90 & Celleporina & grandis & $\mathrm{CH}$ as & ERro & LMC & -0.06 & 1.29 \\
\hline D114 & 44.20 & 173.30 & 84 & Cinctipora & elegans & CY ci & ERro & $\mathrm{LMC} /(\mathrm{A})$ & 1.93 & 1.22 \\
\hline D38 & 51.97 & 165.47 & 252 & Cinctipora & elegans & & & & 1.79 & 1.40 \\
\hline G9 & 48.00 & 166.59 & 170 & Cinctipora & elegans & & & & 1.50 & 1.26 \\
\hline P609 & 40.01 & 174.08 & 75 & Cinctipora & elegans & & & & 0.16 & 1.10 \\
\hline QQ & 45.56 & 170.47 & 80 & Cinctipora & elegans & & & & 0.85 & 0.94 \\
\hline QQ & 45.56 & 170.47 & 80 & Cinctipora & elegans & & & & 1.01 & 0.86 \\
\hline QQ & 45.56 & 170.47 & 80 & Cinctipora & elegans & & & & 1.00 & 0.90 \\
\hline QQ & 45.56 & 170.47 & 80 & Cinctipora & elegans & & & & 0.94 & 0.83 \\
\hline QQ & 45.56 & 170.47 & 80 & Cinctipora & elegans & & & & 0.28 & 1.04 \\
\hline QQ & 45.56 & 170.47 & 80 & Cinctipora & elegans & & & & 0.59 & -0.74 \\
\hline QQ & 45.56 & 170.47 & 80 & Cinctipora & elegans & & & & 0.85 & 0.42 \\
\hline QQ & 45.56 & 170.47 & 80 & Cinctipora & elegans & & & & 1.21 & 0.31 \\
\hline QQ & 45.56 & 170.47 & 80 & Cinctipora & elegans & & & & 1.11 & 0.33 \\
\hline QQ & 45.56 & 170.47 & 80 & Cinctipora & elegans & & & & 0.57 & 0.94 \\
\hline DPG3 & 41.13 & 174.50 & 30 & Cornuticella & taurina & $\mathrm{CH}$ as & EFlt & IMC & 0.57 & -0.55 \\
\hline D44 & 47.50 & 168.01 & 120 & Escharina & waiparensis & $\mathrm{CH}$ as & ENul & IMC & 1.26 & 1.58 \\
\hline DPG2 & 41.17 & 174.67 & 20 & Euthyroides & episcopalis & $\mathrm{CH}$ as & EFlt & IMC & 0.65 & -0.91 \\
\hline DPG4 & 40.80 & 174.17 & 40 & Euthyroides & jellyae & $\mathrm{CH}$ as & EFlt & $\mathrm{IMC} / \mathrm{A}$ & 1.48 & 0.95 \\
\hline B488 & 46.50 & 166.24 & 164 & Foveolaria & cyclops & $\mathrm{CH}$ an & ENul & $\mathrm{IMC} / \mathrm{A}$ & 0.55 & 1.68 \\
\hline D38 & 51.97 & 165.47 & 252 & Foveolaria & cyclops & & & & 2.16 & 1.52 \\
\hline P507 & 34.15 & 172.75 & 100 & Foveolaria & cyclops & & & & 0.37 & 1.59 \\
\hline D38 & 51.97 & 165.47 & 252 & Galeopsis & polyporus & $\mathrm{CH}$ as & ERde & IMC & 1.94 & 0.94 \\
\hline L17 & 36.17 & 174.92 & 52 & Galeopsis & polyporus & & & & 0.84 & 0.10 \\
\hline P448 & 34.39 & 172.47 & 101 & Galeopsis & polyporus & & & & 0.96 & 0.89 \\
\hline P454 & 34.25 & 172.16 & 292 & Galeopsis & polyporus & & & & 1.56 & 1.03 \\
\hline P609 & 40.01 & 174.08 & 75 & Galeopsis & polyporus & & & & -0.33 & 0.38 \\
\hline C10 & 36.38 & 175.38 & 50 & Galeopsis & porcellanicus & $\mathrm{CH}$ as & ERde & IMC & 0.99 & 1.52 \\
\hline DPG5 & 49.75 & 179.00 & & Galeopsis & porcellanicus & & & & 1.87 & 1.69 \\
\hline L13 & 36.20 & 175.04 & 30 & Galeopsis & porcellanicus & & & & -0.67 & 1.56 \\
\hline LF & 36.27 & 174.80 & 8 & Galeopsis & porcellanicus & & & & 0.88 & 0.97 \\
\hline P448 & 34.39 & 172.47 & 101 & Galeopsis & porcellanicus & & & & 1.27 & 1.58 \\
\hline $\mathrm{C} 10$ & 36.38 & 175.38 & 50 & Hippellozoon & novaezelandiae & $\mathrm{CH}$ as & ERfe & IMC & 0.88 & 2.15 \\
\hline P454 & 34.25 & 172.16 & 292 & Hippellozoon & novaezelandiae & & & & 1.76 & 1.83 \\
\hline P507 & 34.15 & 172.75 & 100 & Hippellozoon & novaezelandiae & & & & -0.28 & 1.80 \\
\hline P609 & 40.01 & 174.08 & 75 & Hippellozoon & novaezelandiae & & & & 0.44 & 2.13 \\
\hline E842 & 33.90 & 172.28 & 187 & Hippomenella & vellicata & $\mathrm{CH}$ as & ERfo & $\mathrm{IMC} / \mathrm{A}$ & 0.24 & 1.65 \\
\hline P614 & 40.17 & 174.58 & 90 & Hippomenella & vellicata & & & & 0.43 & 0.94 \\
\hline D38 & 51.97 & 165.47 & 252 & Hornera & spp. & CY ho & ERro & LMC & 1.97 & 1.56 \\
\hline
\end{tabular}


Table 1 (continued)

\begin{tabular}{|c|c|c|c|c|c|c|c|c|c|c|}
\hline \multicolumn{4}{|c|}{ Sample locations } & \multicolumn{5}{|c|}{ Bryozoan species } & \multicolumn{2}{|c|}{ Stable isotopes } \\
\hline $\begin{array}{l}\text { Sample } \\
\text { location }\end{array}$ & $\begin{array}{c}\text { Latitude } \\
\left({ }^{\circ} \mathrm{S}\right)\end{array}$ & $\begin{array}{c}\text { Longitude } \\
\left({ }^{\circ} \mathrm{E}\right)\end{array}$ & $\begin{array}{c}\text { Water } \\
\text { depth }(\mathrm{m})\end{array}$ & Genus & Species & Taxon* & $\begin{array}{c}\text { Growth } \\
\text { form }^{\dagger}\end{array}$ & $\begin{array}{c}\text { Carbonate } \\
\text { mineralogy }\end{array}$ & $\begin{array}{c}\overline{(\mathrm{mg} / \mathrm{g})} \\
\delta^{18} \mathrm{O}\end{array}$ & $\begin{array}{c}\text { VPDB } \\
\delta^{13} \mathrm{C}\end{array}$ \\
\hline E27 & 47.67 & 167.65 & 131 & Hornera & spp. & & & & 1.47 & 1.60 \\
\hline G9 & 48.00 & 166.59 & 170 & Hornera & spp. & & & & 1.80 & 1.61 \\
\hline P448 & 34.39 & 172.47 & 101 & Hornera & spp. & & & & 0.94 & 1.38 \\
\hline P454 & 34.25 & 172.16 & 292 & Hornera & spp. & & & & 1.58 & 1.62 \\
\hline P614 & 40.17 & 174.58 & 90 & Hornera & spp. & & & & 0.60 & 1.57 \\
\hline L13 & 36.20 & 175.04 & 30 & Idmidroneiforms & spp. & CY tu & ERde & LMC & -0.73 & 0.40 \\
\hline P454 & 34.25 & 172.16 & 292 & Iodictyum & yaldwini & $\mathrm{CH}$ as & ERfe & IMC & 1.97 & 1.72 \\
\hline $\mathrm{C} 12$ & 36.49 & 175.38 & 53 & Macropora & grandis & $\mathrm{CH}$ an & ENul & LMC/IMC & 1.00 & -0.08 \\
\hline $\mathrm{C} 10$ & 36.38 & 175.38 & 50 & Mecynoecia & purpurascens & CY tu & ERde & LMC & 0.56 & 0.28 \\
\hline $\mathrm{C} 11$ & 36.40 & 175.40 & 47 & Mecynoecia & purpurascens & & & & -0.80 & -4.50 \\
\hline $\mathrm{C} 12$ & 36.49 & 175.38 & 53 & Mecynoecia & purpurascens & & & & 1.02 & 0.00 \\
\hline LS & 36.27 & 174.80 & 8 & Mecynoecia & purpurascens & & & & 0.36 & -0.64 \\
\hline P507 & 34.15 & 172.75 & 100 & Mecynoecia & purpurascens & & & & 0.12 & 0.62 \\
\hline P609 & 40.01 & 174.08 & 75 & Mecynoecia & purpurascens & & & & 0.53 & -0.51 \\
\hline P614 & 40.17 & 174.58 & 90 & Mecynoecia & purpurascens & & & & 0.15 & -0.02 \\
\hline P507 & 34.15 & 172.75 & 100 & Menipea & zelandica & $\mathrm{CH}$ an & EFbr & LMC & 0.07 & 1.00 \\
\hline P558 & 33.98 & 171.72 & 178 & Menipea & zelandica & & & & 1.56 & 1.37 \\
\hline P454 & 34.25 & 172.16 & 292 & Metroperiella & mисronifera & $\mathrm{CH}$ as & ERro & $\mathrm{IMC} /(\mathrm{A})$ & 1.59 & 2.01 \\
\hline $\mathrm{C} 10$ & 36.38 & 175.38 & 50 & Otionella & squamosa & $\mathrm{CH}$ an & FLvg & $\mathrm{A} /(\mathrm{IMC})$ & 1.37 & 2.58 \\
\hline L17 & 36.17 & 174.92 & 52 & Otionella & squamosa & & & & 1.41 & 2.70 \\
\hline L33 & 36.17 & 174.83 & 58 & Otionella & squamosa & & & & 1.67 & 2.49 \\
\hline P454 & 34.25 & 172.16 & 292 & Otionella & squamosa & & & & 2.75 & 2.65 \\
\hline P492 & 34.36 & 172.61 & 85 & Otionella & squamosa & & & & 1.57 & 2.81 \\
\hline $\mathrm{C} 12$ & 36.49 & 175.38 & 53 & Patsyella & flemingi & $\mathrm{CH}$ an & ENul & $\mathrm{IMC} / \mathrm{A}$ & 1.44 & 0.91 \\
\hline L13 & 36.20 & 175.04 & 30 & Patsyella & flemingi & & & & -0.46 & 0.66 \\
\hline $\mathrm{C} 10$ & 36.38 & 175.38 & 50 & Steginoporella & magnifica & $\mathrm{CH}$ an & ENul & $\mathrm{IMC} /(\mathrm{A})$ & 0.58 & 0.63 \\
\hline P448 & 34.39 & 172.47 & 101 & Steginoporella & magnifica & & & & 0.73 & -0.09 \\
\hline P454 & 34.25 & 172.16 & 292 & Steginoporella & magnifica & & & & 1.64 & -0.03 \\
\hline L13 & 36.20 & 175.04 & 30 & Steginoporella & neozelanica & $\mathrm{CH}$ an & EFrt & IMC & -1.35 & -3.08 \\
\hline OF & 36.72 & 175.83 & 20 & Steginoporella & neozelanica & & & & 0.30 & -1.81 \\
\hline P448 & 34.39 & 172.47 & 101 & Steginoporella & neozelanica & & & & 0.39 & -1.48 \\
\hline P489 & 34.30 & 172.68 & 88 & Steginoporella & perplexa & $\mathrm{CH}$ an & ENul & $\mathrm{IMC} /(\mathrm{A})$ & 0.72 & -1.06 \\
\hline P507 & 34.15 & 172.75 & 100 & Steginoporella & perplexa & & & & -0.13 & -1.08 \\
\hline $\mathrm{C} 12$ & 36.49 & 175.38 & 53 & Telopora & buski & CY fa & ERra & LMC & 0.55 & 0.78 \\
\hline L10 & 36.20 & 174.92 & 53 & Telopora & buski & & & & 0.94 & 1.02 \\
\hline L21 & 36.08 & 175.04 & 71 & Telopora & buski & & & & 0.92 & 0.89 \\
\hline P507 & 34.15 & 172.75 & 100 & Telopora & buski & & & & 0.49 & 1.39 \\
\hline P609 & 40.01 & 174.08 & 75 & Telopora & buski & & & & -0.57 & 1.06 \\
\hline$n$ & & & & 25 & 30 & 4 & 12 & 7 & 103 & 103 \\
\hline Min. & 33.90 & 165.47 & 8 & & & & & & -1.35 & -4.50 \\
\hline Max. & 51.97 & 179.00 & 292 & & & & & & 2.75 & 2.81 \\
\hline Mean & 39.68 & 172.41 & 111 & & & & & & 0.93 & 0.96 \\
\hline
\end{tabular}

*Taxonomic abbreviations: CH Cheilostomata: an anascan, as ascophoran. CY Cyclostomata: ci cinctiporid, fa fasciculate, ho horneroid, tu tubuliporine.

${ }^{\dagger}$ Growth form abbreviations (adapted from Nelson et al. 1988; Smith 1992; Hageman 1998): EN encrusting: ml multilaminar, ul unilaminar, nd nodular. ER erect rigid: de delicate branching, fe fenestrate, fo foliose, ra radiate, ro robust branching. EF erect flexible: br branching, lt lightly calcified, rt rooted. FL free-living: vg vagrant.

$\$$ Mineralogical abbreviations (data from Smith et al. 1998): A Aragonite; LMC low Mg calcite (<5 wt\%); IMC intermediate Mg calcite $(5-10 \mathrm{wt} \%)$. Where two minerals are listed, the first is dominant, the second subdominant. Where a mineral is in parentheses, it is found in trace amounts only in a few specimens.

dried, and ground to powder. Small samples were roasted at $200^{\circ} \mathrm{C}$ to remove organic contaminants, crushed, and reacted completely with $100 \%$ orthophosphoric acid at $50^{\circ} \mathrm{C}$. Stable isotope ratios of the resulting $\mathrm{CO}_{2}$ gas were determined using a VG Micromass 602E mass spectrometer at the University of Waikato, after the method of Shackleton (1965). Values are given in delta notation as per mil deviation of the ${ }^{18} \mathrm{O} /{ }^{16} \mathrm{O}$ and ${ }^{13} \mathrm{C} /{ }^{12} \mathrm{C}$ in the sample relative to the VPDB standard (i.e., $\delta^{18} \mathrm{O}$ and $\delta^{13} \mathrm{C}$, respectively) by repeated analyses of the international standard NBS-19. Analytical precision for isotopic analyses is \pm 0.05 to $0.1 \%$.
A single colony of Cinctipora elegans from the Otago shelf (QQ in Table 1) was thin-sectioned and polished on the exposed upper surface. Micromilling of skeletal carbonate was performed (sensu Wurster et al. 1999) on a computer controlled, 3D positioning stage set under a fixed highprecision dental drill with $1 \mu \mathrm{m}$ spatial sampling resolution, resulting in powdered samples of $20-40 \mu \mathrm{g}$ for carbon and oxygen isotopic analysis. The 10 carbonate samples (five from the interior, thin-walled zooecia (endozone) and five from the exterior, thick-walled zooecia (exozone)) were roasted in vacuo at $200^{\circ} \mathrm{C}$ to remove water and volatile organic 


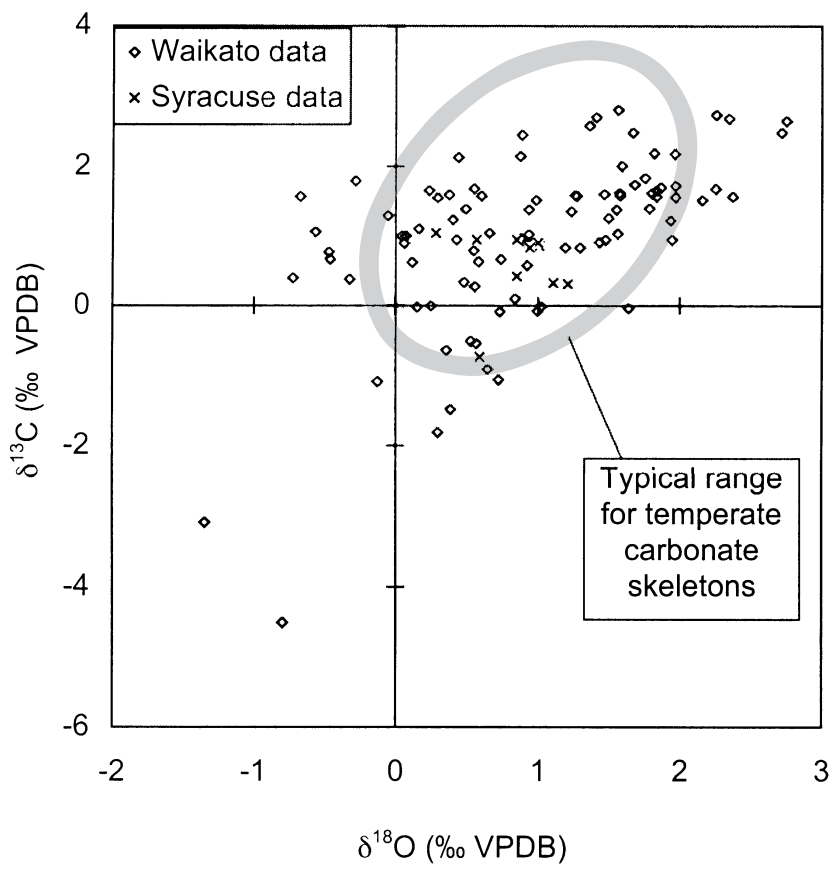

Fig. 2 Oxygen and carbon stable isotopes for 103 specimens of 30 species of extant bryozoans from New Zealand with the typical range for temperate carbonate skeletons circled (from Rao \& Nelson 1992).

contaminants. Stable isotope values were obtained using a Finnigan Kiel-III automated carbonate preparation system directly coupled to the inlet of a Finnigan MAT 252 gas ratio mass spectrometer in the stable isotope laboratory at Syracuse University. Carbonate was reacted at $70^{\circ} \mathrm{C}$ with two drops of anhydrous phosphoric acid for $90 \mathrm{~s}$. Isotopic ratios were corrected for acid fractionation and ${ }^{17} \mathrm{O}$ contribution, and reported in per mil notation relative to the VPDB standard (i.e., $\delta^{18} \mathrm{O}$ and $\delta^{13} \mathrm{C}$ ). Precision and calibration of data were monitored through daily analysis of NBS-18 and NBS-19 carbonate standards, which bracketed the $\delta^{18} \mathrm{O}$ values of the samples. Precision for these samples is better than $\pm 0.1 \%$ o for both carbon and oxygen isotope values.

\section{RESULTS}

Stable isotope results are given in Table 1 . The 103 bryozoan samples have $\delta^{18} \mathrm{O}$ values ranging from -1.4 to $2.8 \%$, with a mean of $0.9 \%$ and $\delta^{13} \mathrm{C}$ values from -4.5 to $2.8 \%$, with a mean of $1.0 \%$.

The 30 bryozoan species selected came from 25 genera, 2 orders, and 2 classes. The 30 species comprised 12 different growth forms (sensu Nelson et al. 1988b; Smith 1992; Hageman 1998): 3 encrusting forms, 5 erect rigid forms, 3 erect flexible forms, and 1 free-living form (Table 1). Carbonate mineralogy among the species studied also covered a wide range, from mainly aragonite to entirely calcite, including low-Mg and intermediate-Mg calcite (Smith et al. 1998), as well as two species that precipitate both forms of calcite (Table 1). There were seven combinations of carbonate minerals among the New Zealand specimens.

Replicate stable isotope values from a single branch of Cinctipora elegans from the Otago shelf (QQ in Table 1) cover

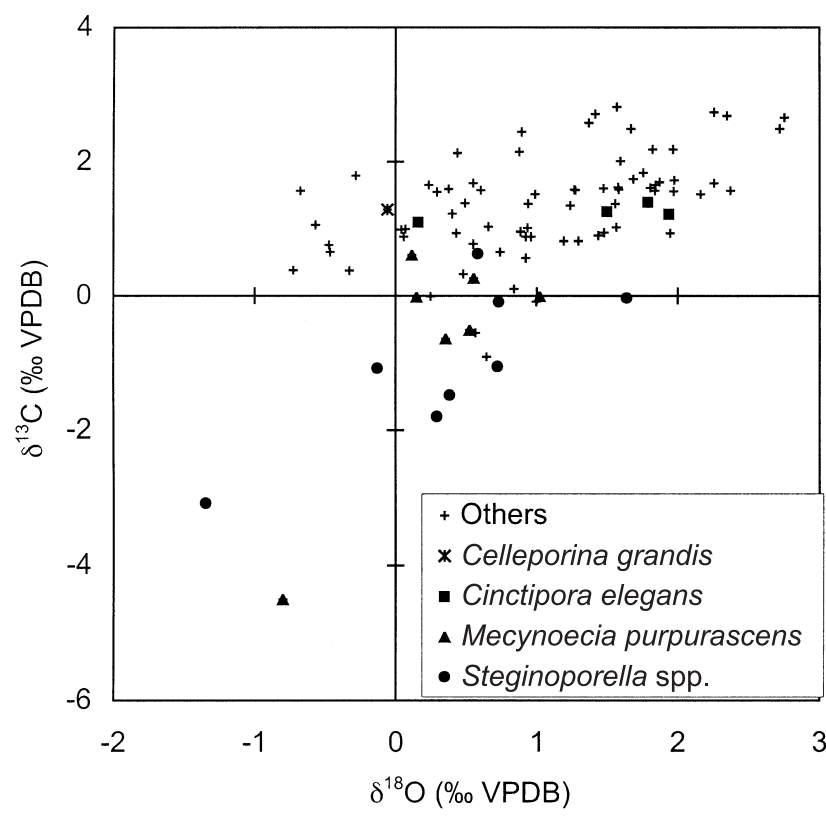

Fig. 3 Oxygen and carbon stable isotopes for species in which one or more specimens lie well outside the typical range for temperate marine carbonate.

a narrower range than the other New Zealand shelf specimens. $\delta^{18} \mathrm{O}$ values varied from 0.3 to $1.2 \%$, with a mean of $0.8 \%$, while $\delta^{13} \mathrm{C}$ ranged from -0.7 to $1.0 \%$, with a mean of $0.6 \%$ o (Table 1, Fig. 2).

\section{DISCUSSION}

\section{Isotopic equilibrium in bryozoans}

Many marine invertebrates secrete a skeleton in which the carbonate is close to isotopic equilibrium with the $\mathrm{CO}_{2}$ of ambient sea water (Corfield 1995). Likewise, most bryozoans have been shown to precipitate carbonate near isotopic equilibrium with sea water (Forester et al. 1973; Rao \& Nelson 1992; Bone \& James 1996; Crowley \& Taylor 2000). But bryozoans such as Celleporina grandis with internal symbiotic hydroids may not (Crowley \& Taylor 2000), possibly due to the effects of respiration. Indeed, our single specimen of $C$. grandis shows an unusually low oxygen isotope value (Fig. 3), consistent with vital fractionation.

The relatively wide spread of the bryozoan stable isotope data (Fig. 2) reflects the wide range of shelf environments sampled, from warm to cold temperate (i.e., 34-54 $\mathrm{S}$ latitude) and from coastal to deep shelf waters (i.e., 8-292 m). Most of the data fall well within the normal field for cool-water carbonates (Fig. 2), but there are a few outliers exhibiting unusually low stable isotope values (Fig. 3).

The lowest carbon isotope value $(-4.5 \%$ ) coincides with a low oxygen value $(-0.8 \%)$ in a specimen of Mecynoecia purpurascens from outer Hauraki Gulf. The other six specimens of $M$. purpurascens in the dataset, two of which come from adjacent samples in Hauraki Gulf, show normal values (Fig. 3). Cinctipora elegans, too, has only one sample with an unusually low oxygen value. In these cases it may be 


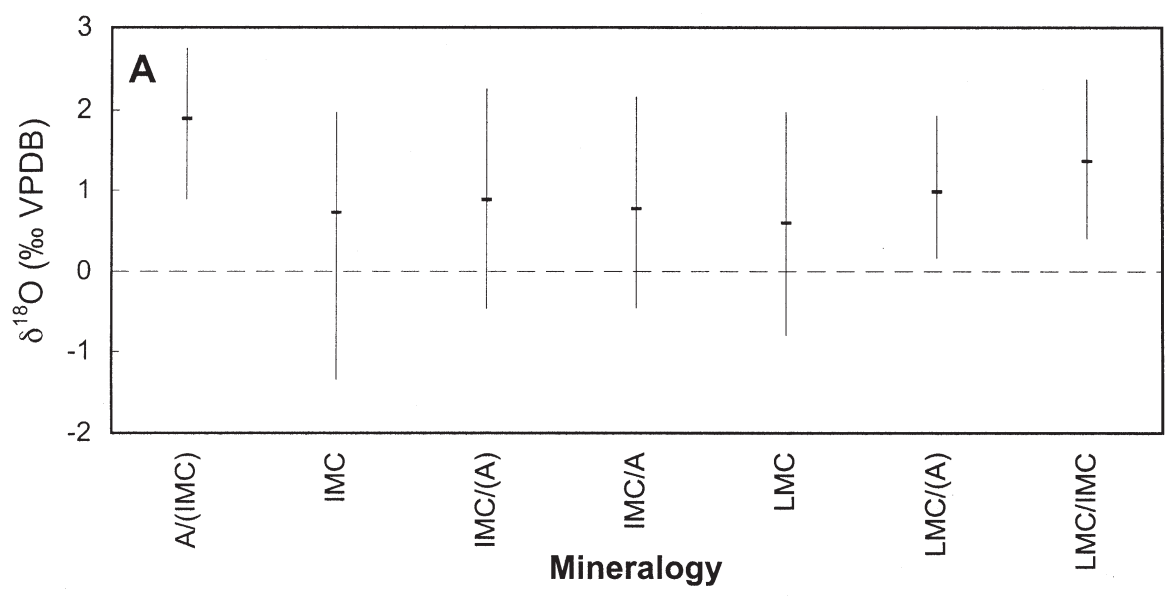

Fig. 4 Range and mean of oxygen (A) and carbon (B) stable isotopes in bryozoan carbonate of different mineralogies $(\mathrm{A}=$ aragonite, $\mathrm{LMC}$ $=$ low $\mathrm{Mg}$ calcite with $<5 \mathrm{wt} \%$ $\mathrm{MgCO}_{3}, \mathrm{IMC}=$ intermediate $\mathrm{Mg}$ calcite with 5-10 wt $\% \mathrm{MgCO}_{3}$ ). Where two minerals are listed, the first is dominant and the second subdominant. Where a mineral is in parentheses, it is found in trace amounts in only a few specimens.

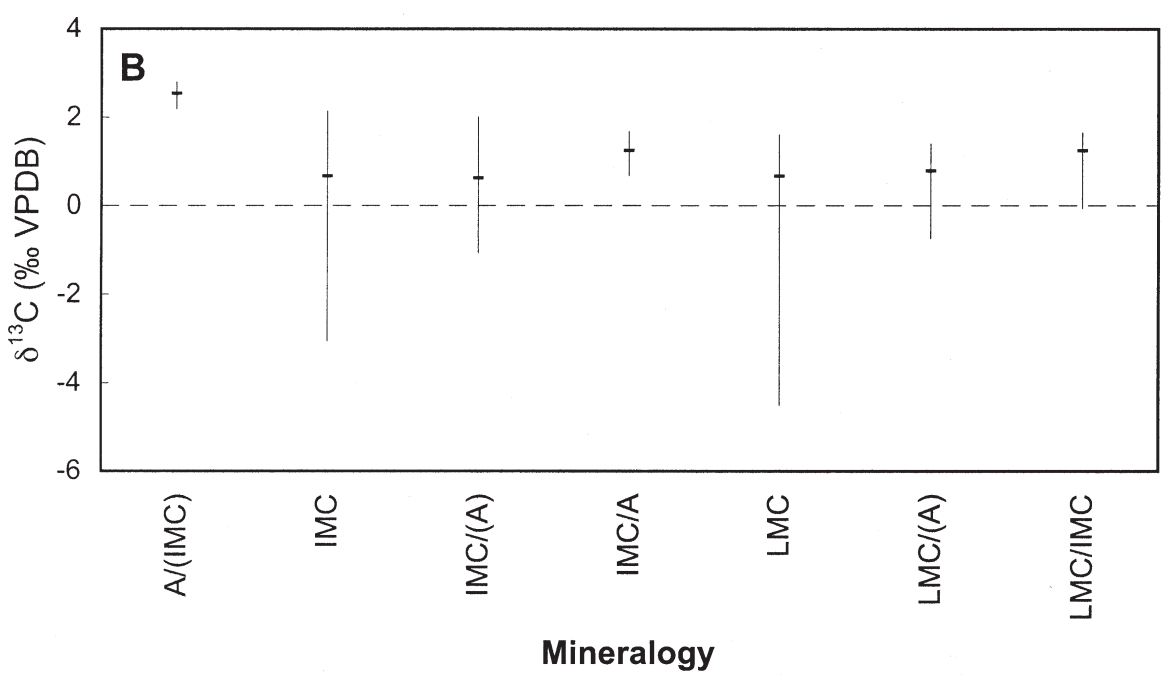

that single relict specimens showing some degree of diagenetic alteration, perhaps in meteoric water, have been inadvertently included. Sample contamination by epibiotic organisms could result in such a distribution, although care was taken to avoid such contamination in sample preparation.

The samples of genus Steginoporella, however, show a different range of isotope values. One specimen of Steginoporella neozelanica yields the lowest oxygen value in the dataset $(-1.4 \%$ ) , along with a low carbon value $(-3.1 \%$ o) In this case, other specimens of Steginoporella (including the species $S$. perplexa and $S$. magnifica) also show low carbon values. This pattern suggests that at least some species within the genus probably do not precipitate carbonate in isotopic equilibrium with sea water, exerting some kinetic effect.

\section{Temperate regime}

In general, tropical marine carbonates have $\delta^{18} \mathrm{O}$ values ranging from c. -4 to $1 \%$, and higher $\delta^{13} \mathrm{C}$ values $(-2$ to $5 \%$ ) (see, e.g., Nelson \& Smith 1996). Low oxygen values reflect high sea-water temperatures, and high carbon values may be due, at least in part, to algal metabolic activity (Nelson \& Smith 1996). The few modern temperate carbonates studied previously, principally from off southern Australia and Tasmania, have shown a different relationship (Rao \& Green 1983; Rao \& Nelson 1992). There, $\delta^{13} \mathrm{C}$ values are intermediate, with a narrower range $\left(-0.2\right.$ to $2 \%$ ), and $\delta^{18} \mathrm{O}$ are higher ( -2 to $2 \%$ ), reflecting cool temperate conditions. The New Zealand bryozoans reported here fall in the temperate carbonate field, but with a slightly wider range of $\delta^{13} \mathrm{C}$ values (-2 to $3 \%$ ) and higher $\delta^{18} \mathrm{O}$ values (0 to $3 \%$ ) (Fig. 2).

New Zealand bryozoans cover a wider isotope range than New Zealand carbonate sediments, reflecting the averaging effect of bulk sediment sampling. The positive diagenetic co-variation identified by Rao \& Nelson (1992) in Tasmanian carbonates is less obvious in the New Zealand specimens $\left(\delta^{13} \mathrm{C}=0.8 \delta^{18} \mathrm{O}+0.2 ; R^{2}=0.32\right)$, but may still appear within some species. Despite their regional differences, both sets of temperate data clearly occupy a different range of values from their tropical counterparts.

\section{Mineralogy and stable isotope values}

In aragonite, vaterite, and high-Mg calcite, $\delta^{18} \mathrm{O}$ and $\delta^{13} \mathrm{C}$ are enriched relative to low-Mg calcite (Tarutani et al. 1969). New Zealand bryozoans show isotope enrichment in aragonite, but less in intermediate-Mg calcites (Fig. 4). A similar observation 
was made in Tasmanian bryozoans (Rao \& Green 1983), and in some bryozoans from the Lacepede Shelf, South Australia (Bone \& James 1997).

While most bryozoan species from this study are low or intermediate $\mathrm{Mg}$ calcite, many (47\%) are bimineralic. For example, not one species listed here is entirely aragonitic - in each one at least some specimens contain at least some calcite, usually intermediate- $\mathrm{Mg}$ calcite $\left(5-10 \mathrm{wt} \% \mathrm{MgCO}_{3}\right)$ rather than low-Mg calcite $\left(0-4 \mathrm{wt} \% \mathrm{MgCO}_{3}\right)$. Some calcitic species contain the occasional specimen with some aragonite (20\%), and there are also species which combine dominant low-Mg calcite with some intermediate-Mg calcite (20\%). There are no known species of bryozoan which consistently precipitate high-Mg calcite, with $>10$ wt $\% \mathrm{MgCO}_{3}$ (Smith et al. 1998). Seven different mineralogical combinations are found among the 30 species listed here (Appendix 1).

The relationship of mineralogy to stable isotopes is well documented, as high-Mg calcite and aragonite both concentrate heavier oxygen isotopes (c. $0.6 \%$ higher) and carbon isotopes (c. $1.5 \%$ higher) than calcite precipitated under the same conditions (see, e.g., Bone \& James 1997; Rahimpour-Bonab et al. 1997b; Crowley \& Taylor 2000). Such mineralogical effects can be removed by calculating the calcite-equivalent isotope values (e.g., Tarutani et al. 1969; Romanek et al. 1992). In the case of our bryozoans, however, mixed mineralogies and variable proportions of different minerals among specimens make such calculations problematic. We have elected not to transform our data because of this complexity. Regardless, most bryozoans are monomineralic or contain only trace amounts of a secondary mineral, and they are the ones which should be used for paleoenvironmental reconstruction.

As expected, aragonite-dominated specimens (comprising two species) show the highest mean oxygen isotope values, with low-Mg calcite (seven species) giving the lowest mean (Fig. 4A). Aragonite-dominated specimens $(n=11$, mean $=1.9 \%$ VPDB) have significantly higher $\delta^{18} \mathrm{O}$ compared to the other mineralogies $(n=92$, mean $=0.8 \%$ ) $(t$-test, $P<0.001)$. Low-Mg calcite specimens have significantly lower $\delta^{18} \mathrm{O}(n=24$, mean $=0.6 \%$ VPDB $)$ compared to the other mineralogies $(n=79$, mean $=1.0 \%$ VPDB $)(t$-test, $P<0.001)$. There is no significant difference among the other mainly calcite mineralogies.

The aragonite-dominated specimens also show high carbon isotope values, and in a narrow range (Fig. 4B). Aragonite-dominated specimens have significantly higher $\delta^{13} \mathrm{C}(n=11$, mean $=2.5 \%$ VPDB $)$ compared to the other mineralogies $(n=92$, mean $=0.8 \%$ VPDB $)(t$-test, $P<0.001$ ). The four species (eight specimens) consisting of intermediate- $\mathrm{Mg}$ calcite with subdominant aragonite also cover a more narrow range of carbon isotopes than all the other calcite combinations (Fig. 4B). It has been suggested elsewhere that low-Mg calcite-precipitating bryozoans exert vital fractionation effects more often than do aragonitic or intermediate-Mg calcitic bryozoans (Bone \& James 1997), perhaps due to variations in growth rate, which could explain the much greater variability within the low-Mg calcite bryozoans.

The mineralogical complexity inherent in bryozoan skeletons must be acknowledged in all geochemical work with this phylum. In particular, paleoenvironmental reconstruction using geochemical proxies such as $\delta^{18} \mathrm{O}$ can only be reliable in species whose mineralogy is well constrained.

\section{Taxonomic position}

The 30 species studied here fall into two different orders in two different classes. The Order Cyclostomata in the Class Stenolaemata is an ancient marine clade, persisting since the Ordovician Period and particularly dominant during the Mesozoic Era. Of the six sub-groups in the Cyclostomata (after Boardman 1998), four are represented in our dataset (Table 1): the horneroids (6 specimens, 1 genus with undescribed species), tubuliporines, (10 specimens, 3 species), fasciculates (5 specimens, 1 species), and Cinctiporids (14 specimens, 1 species).

Cheilostomate bryozoans (Class Gymnolaemata, Order Cheilostomata) became dominant in the Cretaceous Period. They are thus younger evolutionarily but morphologically more complex and taxonomically more diverse than cyclostomes. Cheilostomates are divided into the superfamilies Anasca (28 specimens, 9 species in this study) and Ascophora (30 specimens, 13 species).

Because of the variable sample numbers among the sub-groups, comparisons can only be suggestive. There is, however, no apparent phylogenetic effect on either oxygen or carbon isotopes in bryozoans (Fig. 5). There are no significant differences between cheilostomes and cyclostomes in either their $\delta^{18} \mathrm{O}$ or $\delta^{13} \mathrm{C}$ values ( $t$ tests, $P>0.05$ ). Not surprisingly, the variability in groups where we have only one species represented is much less than those covering a wider taxonomic range.

\section{Growth form}

Bryozoans are exceptionally variable in terms of their colonial growth forms (e.g., Nelson et al. 1988b; Hageman 1998). Our group of 30 species consists of 12 different growth forms. Figure 6 shows there are some differences in isotopic composition among these colonial growth forms.

The New Zealand dataset contains three encrusting forms: thick multilaminar encrusters (1 species), nodule-formers (1 species), and thin unilaminar encrusters (8 species) (Appendix 1). All three groups generally show a wide range of oxygen isotope values and a narrow range of carbon isotope values (Fig. 6)

Erect flexible branching (2 species), lightly calcified (3 species), and rooted (1 species) forms show a similar degree of variability. The extremely low isotopic values for the erect flexible rooted category results from the possible disequilibrium fractionation by Steginoporella neozelanica, the species that makes up this category.

Erect rigid forms vary from the delicate branching (4 species), radiate (1 species), fenestrate (2 species), foliose (1 species), and robust branching (6 species) forms. The extremely low variability among some of these categories is partially the result of single-species categories, but may also indicate environmental preferences among some growth forms (e.g., Smith 1995). The free-living vagrant (1 species) is the most heavily aragonitic of the species in the study. Its high isotope values are thus explained by carbonate mineralogy.

A growth form classification of bryozoans was suggested by Nelson et al. (1988b) as a way to simplify identification. Mineralogical groupings among growth forms have been elucidated by Bone \& James (1993), and ecological preferences have also been suggested for particular growth forms (e.g., Smith 1995). There is also probably some phylogenetic overprint for growth form. There is no way to decouple growth form from these confounding factors, and 

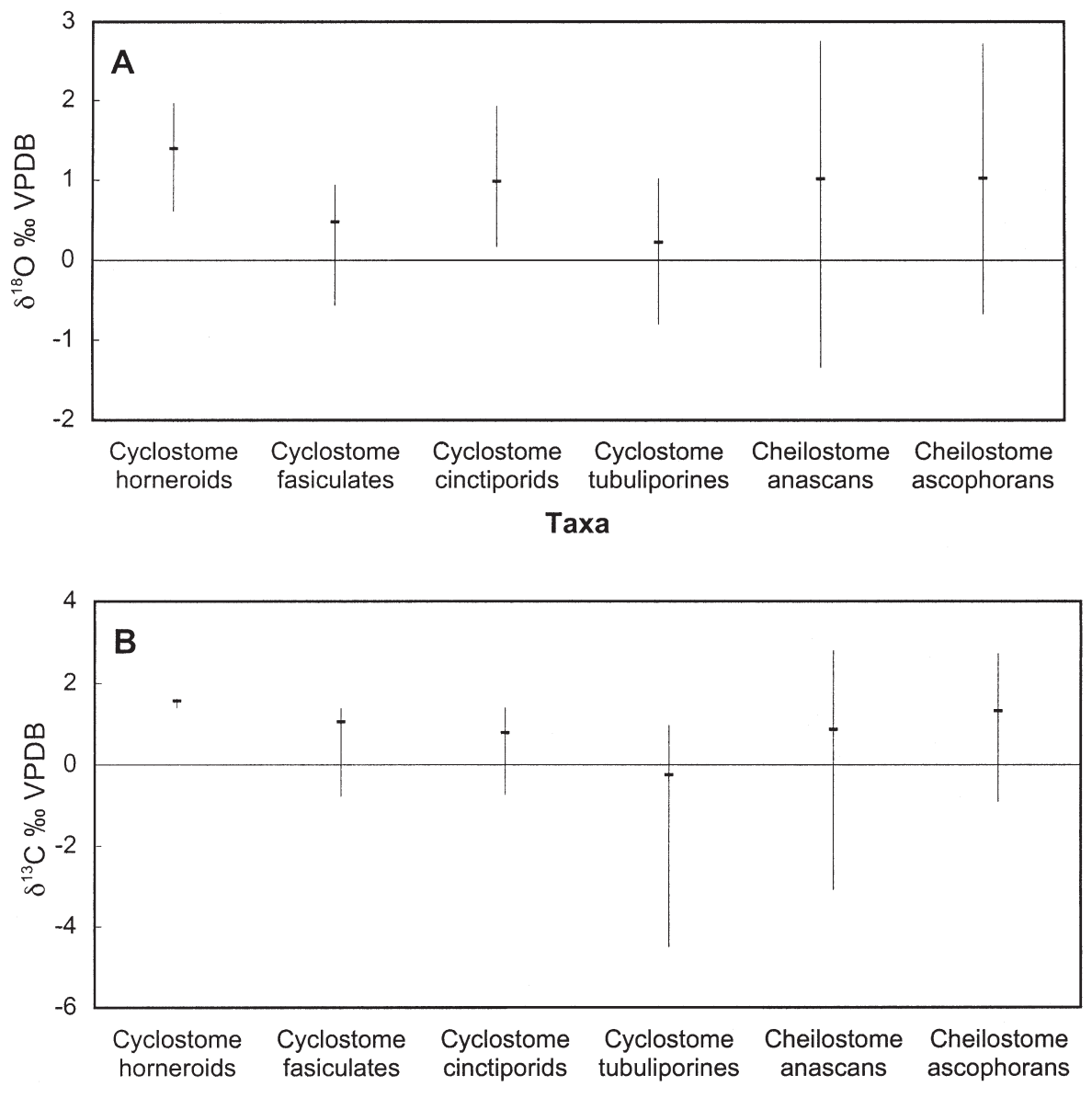

Taxa
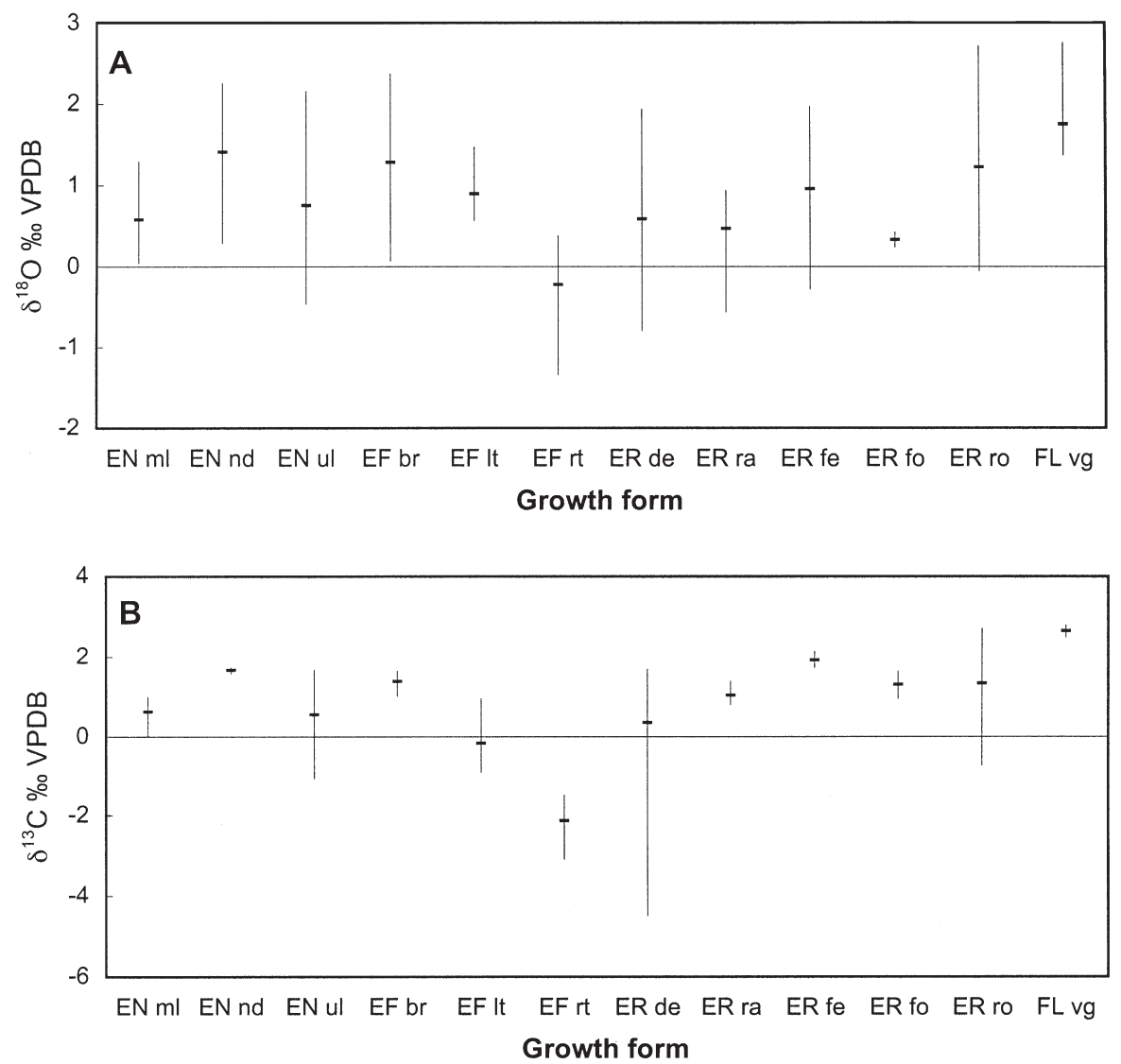

Fig. 5 Range and mean of oxygen (A) and carbon (B) stable isotopes in bryozoan carbonate of different phylogenetic positions.
Fig. 6 Range and mean of oxygen (A) and carbon (B) stable isotopes in bryozoan carbonate of different colony growth forms (EN = encrusting: ml, multilaminar; ul, unilaminar; nd, nodular. $\mathrm{ER}=$ erect rigid: de, delicate branching; fe, fenestrate; fo, foliose; ra, radiate; ro, robust branching. $\mathrm{EF}=$ erect flexible: br, branching; lt, lightly calcified; $r t$, rooted. $\mathrm{FL}=$ free living: vg, vagrant). 
Fig. 7 Oxygen and carbon stable isotopes in bryozoan skeletons across latitudes (A) and water depths (B).
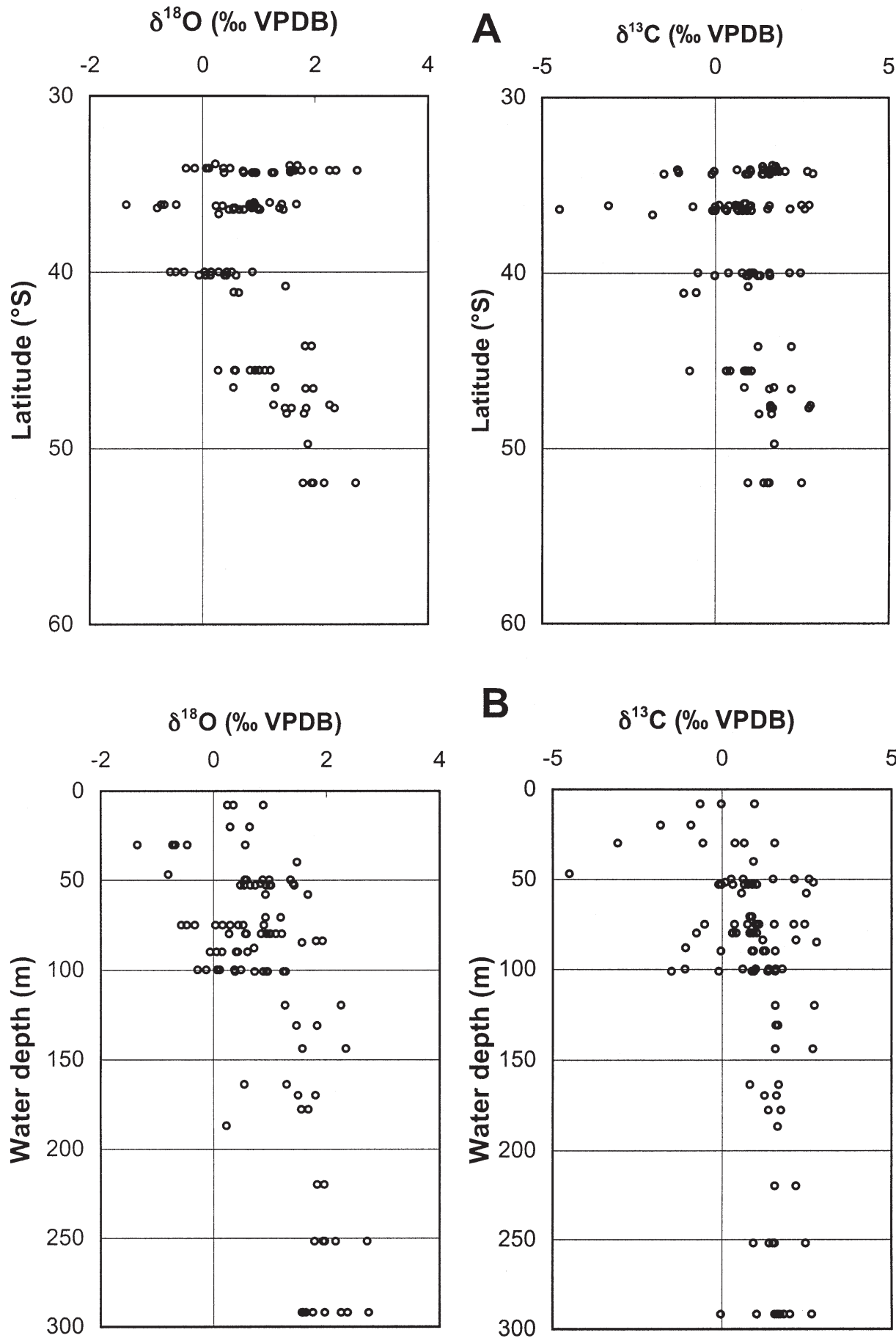

B
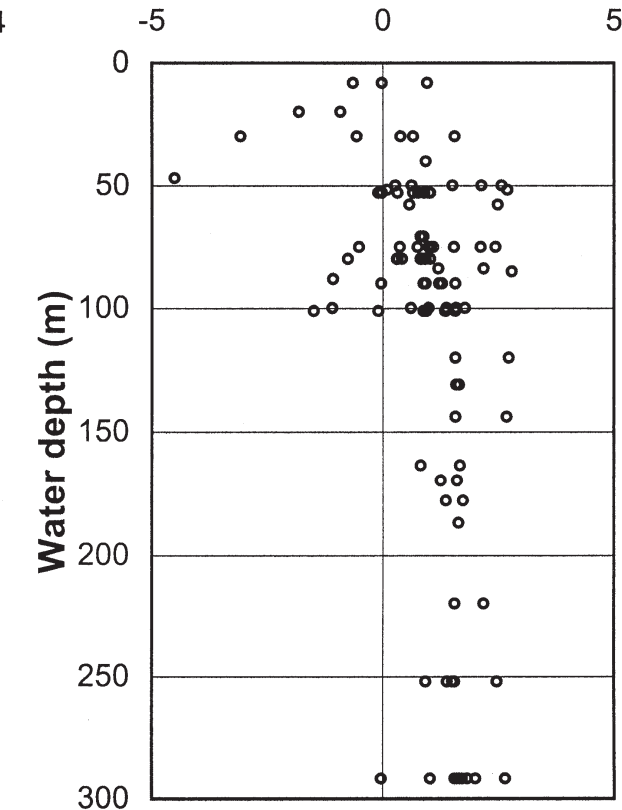

indeed there seems to be no mechanism by which bryozoans of a particular morphology would necessarily have a particular isotopic signature.

\section{Environment}

The most important geological application for oxygen isotopes has been in calculating paleotemperature. A simple binomial relationship between $\delta^{18} \mathrm{O}$ and temperature of formation (e.g, Kim \& O’Neil 1997) appears to give consistent results in modern carbonates. Applied only to the calcitic New Zealand bryozoans considered here, the formula gives temperatures of $7-15^{\circ} \mathrm{C}$ (Smith \& Nelson 1993; Smith \& Key 2004), similar to New Zealand shelf bottom temperatures which typically range from 9 to $15^{\circ} \mathrm{C}$ (Rao \& Nelson 1992). There is significant scatter in Fig. 7A, but nevertheless cold highlatitude samples have both high $\delta^{18} \mathrm{O}$ values, as expected, and a narrower range of temperatures than the samples from warmer temperate regions.

In general, one expects water depth to have an effect on isotope composition since temperature of bottom water decreases as depth increases (Rao \& Nelson 1992; Amini \& Rao 1998). Superimposed on this is a water mass signaturedeep waters often have lower DIC $\delta^{13} \mathrm{C}$ values (e.g., Kroopnick 1974, Rao \& Green 1983). Within each of the shelf, slope, 

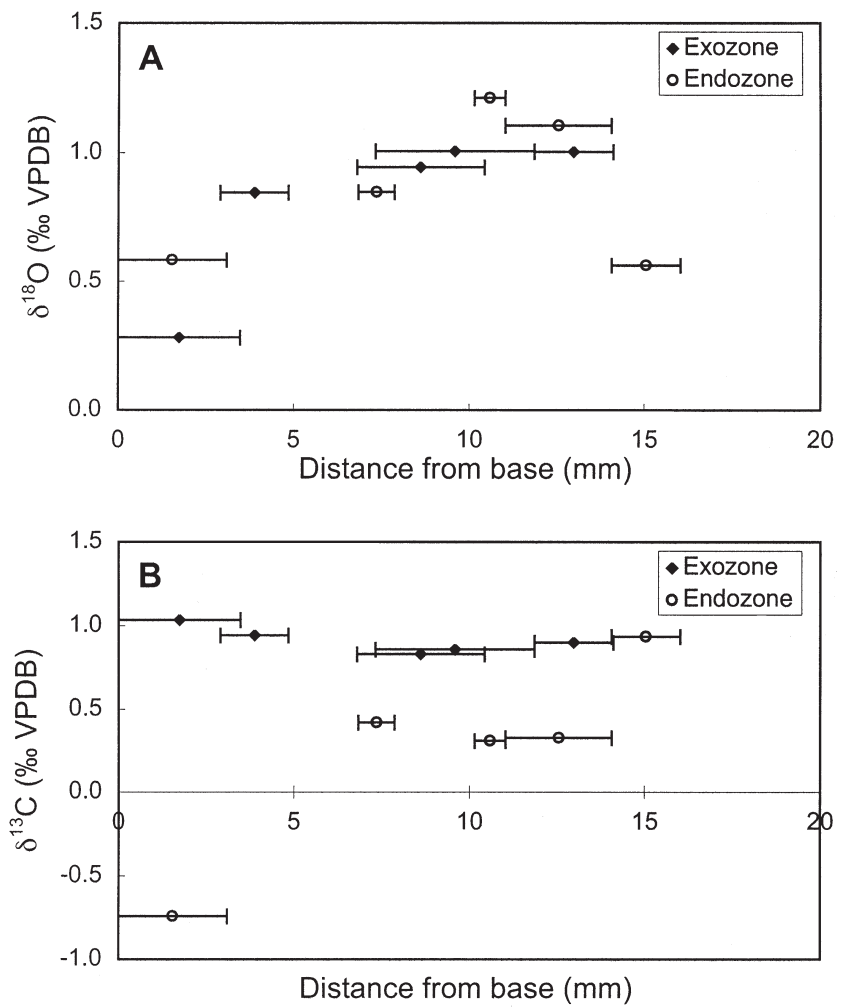

Fig. 8 Variation in oxygen $(\mathbf{A})$ and carbon $(\mathbf{B})$ stable isotopes along a single branch of Cinctipora elegans from the Otago shelf.

and deep-sea settings, in general, $\delta^{18} \mathrm{O}$ and $\delta^{13} \mathrm{C}$ values in carbonate increase with depth (and decreasing temperature), but there are considerable differences among the settings, particularly as DIC $\delta^{13} \mathrm{C}$ values decrease with water depth.

The New Zealand bryozoans used in this study were collected no deeper than $300 \mathrm{~m}$. Within the shelf setting, the trend in New Zealand bryozoans is for $\delta^{18} \mathrm{O}$ and $\delta^{13} \mathrm{C}$ values to increase with depth (Fig. 7B), consistent with observations from elsewhere (e.g., Rao \& Nelson 1992). There is a significant $(P<0.001)$ positive linear correlation between water depth and $\delta^{18} \mathrm{O}\left(R^{2}=0.414\right)$, and a significant $(P<0.001)$ but weak $\left(R^{2}=0.141\right)$ positive linear correlation between water depth and $\delta^{13} \mathrm{C}$.

\section{Within-colony variation}

Oxygen isotope values along a single branch of Cinctipora elegans show little variation along the branch. In contrast, carbonate at the colony surface (exozone) shows higher carbon isotope values than the corresponding endozone (carbonate material closer to the centre of the branch), although it is not statistically significant ( $t$-test, $P>0.05$ ). Exozone carbon isotope values are fairly consistent along the branch, whereas the endozone material became significantly $\left(R^{2}=0.83, P=0.03\right)$ higher with distance from the base in the colony sampled (Fig. 8).

We have no explanation for this hitherto unknown observation. There may be some mechanism whereby the source of carbon is different for endozone and exozone carbonate. Perhaps growth rate, and hence precipitation rate, is different. Or maybe metabolic factors influence the endozone but not the more distal exozone. This should be a fruitful area for further investigation.

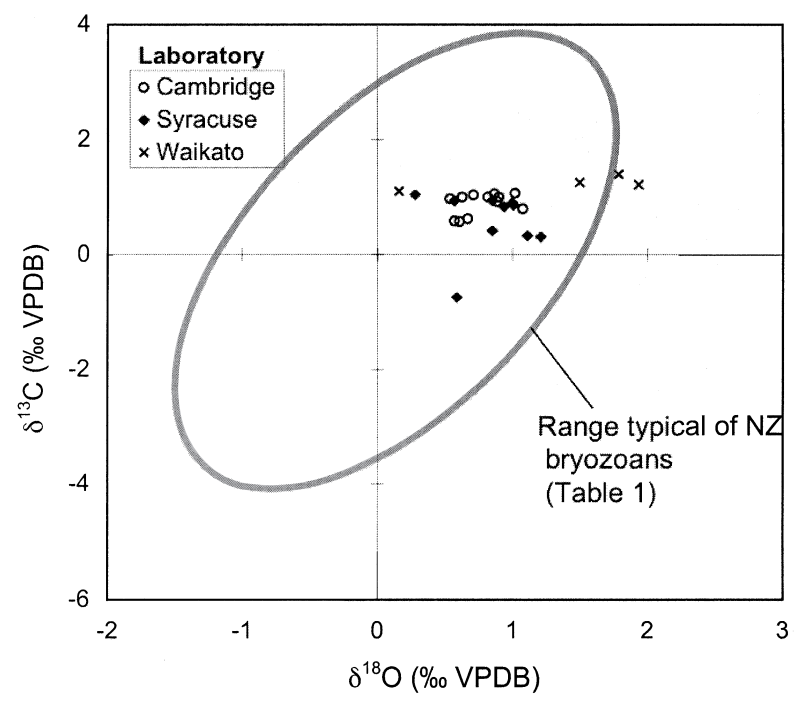

Fig. 9 Comparison of oxygen and carbon stable isotopes derived from similar skeletal material of Cinctipora elegans from the Otago shelf, measured at three different laboratories.

\section{Cross-correlation of results}

Interpretation of stable isotope data can be problematic, and additionally confounded by inconsistencies of sample preparation, collection times, and measurements. We have here an opportunity to compare similar datasets analysed in three different laboratories with different protocols. Stable isotopes in the low-Mg calcite cyclostomate bryozoan Cinctipora elegans from the Otago shelf were analysed in two of the laboratories (Cambridge and Syracuse), and another four samples of the same species from the open shelf around New Zealand's South Island were analysed at Waikato.

The C. elegans data cover a small range of carbon isotope values compared to the total range in both this study and that of Crowley \& Taylor (2000). Oxygen isotope values are more variable, especially in the Waikato data, no doubt due to the wider geographic spread and corresponding wider range in water temperatures. There are no significant differences between the Waikato and Syracuse samples in either their $\delta^{18} \mathrm{O}$ or $\delta^{13} \mathrm{C}$ values ( $t$-tests, $\left.P>0.05\right)$. The agreement between the Waikato and Syracuse data and Crowley \& Taylor's (2000) Otago study is encouraging and indicates the reliable nature of the data (Fig. 9).

\section{CONCLUSIONS}

Many bryozoans appear to precipitate carbonate (both calcite and aragonite) in isotopic equilibrium with ambient sea water. Exceptions may, however, occur, particularly in the case of Celleporina grandis, which harbours a symbiotic hydroid, and Steginoporella neozelanica. Any further isotopic study must ascertain the degree of vital fractionation before assuming bryozoan stable isotopes in a particular species to be reliable (paleo)environmental indicators.

Stable isotope values of New Zealand bryozoans fall, as expected, in a range typical of temperate carbonates, with $\delta^{18} \mathrm{O}$ from -1.4 to $2.8 \%$ VPDB, and $\delta^{13} \mathrm{C}$ from -4.5 to $2.8 \%$ o VPDB. There is a distinctive temperate isotope signature with higher $\delta^{18} \mathrm{O}$ values relative to tropical carbonates, 
which reflects the considerable differences between the two environments of deposition.

Both oxygen and carbon isotope values are naturally higher in aragonite than in calcite. In aragonite, $\delta^{18} \mathrm{O}$ is elevated by $1-2 \%$ PDB, and $\delta^{13} \mathrm{C}$ by c. $1 \%$ VPDB. The complex and variable mineralogies of bryozoans make simple isotopic corrections difficult.

Whereas phylogenetic position and colony growth form are not obviously linked to stable isotope signatures, environment of deposition can be. There is a strong trend in bryozoans from the New Zealand shelf to have higher isotope values with higher latitudes and deeper waters, both related to temperature.

While there is variability among bryozoan specimens and species, it is less within a single colony. Nevertheless, an intriguing trend in carbon isotope values along a branch of Cinctipora elegans suggests that, at least in this species, endozone and exozone carbonate may be recording seawater carbon isotopes differently, perhaps due to different calcification histories. Our results from three different laboratories on a single population from a single location are encouragingly consistent.

Bryozoan isotope studies have been used to infer age of colonies (Pätzold et al. 1987; Brey et al. 1999; Bader 2000), to describe modern climate variation (Smith \& Key 2004), to determine paleotemperatures (Rao \& Jayawardane 1994), and to describe past environments in deep-sea sediments (Machiyama et al. 2003). We suspect that geochemical application of bryozoans for helping characterise the environmental conditions accompanying modern and ancient sediment facies has been underutilised in favour of other taxa such as brachiopods. Given the importance of bryozoans as biotic contributors throughout much of the Phanerozoic record, their chemical utility is likely to increase in future studies.

\section{ACKNOWLEDGMENTS}

We thank Steve Cooke (Waikato), Matthew Dustin Moore (Dickinson), and Christina Hartman (Syracuse) for stable isotope analysis, and the University of Waikato, University of Otago, and Dickinson College for their support of this work. Key's funding came from the Research and Development Committee of Dickinson College and the Whitaker Foundation. Smith and Nelson acknowledge support provided by the former New Zealand University Grants Committee.

\section{REFERENCES}

Amini, Z. Z.; Rao, C. P. 1998: Depth and latitudinal characteristics of sedimentological and geochemical variables in temperate shelf carbonates, eastern Tasmania, Australia. Carbonates and Evaporites 13: 145-156.

Anderson, T. F. 1990: Temperature from oxygen isotope ratios. In: Briggs, D. E. G.; Crowther, P. R. ed. Palaeobiology: a synthesis. Oxford, Blackwell. Pp. 403-406.

Bader, B. 2000: Life cycle, growth rate, and carbonate production of Cellaria sinuosa. In: Herrera Cubilla, A.; Jackson, J. B. C. $e d$. Proceedings of the 11th International Bryozoology Association Conference, Smithsonian Tropical Research Institute, Balboa. Pp. 136-144.

Boardman, R. S. 1998: Reflections on the morphology, anatomy, evolution, and classification of the Class Stenolaemata (Bryozoa). Smithsonian Contributions to Paleobiology $86.59 \mathrm{p}$.
Bone, Y.; James, N. P. 1993: Bryozoans as carbonate sediment producers on the cool-water Lacepede shelf, southern Australia. Sedimentary Geology 86: 247-271.

Bone, Y.; James, N. P. 1996: Stable isotopes: do all cool-water bryozoans equally reflect the same parameters? Geological Society of Australia Abstracts 41: 48.

Bone, Y.; James, N. P. 1997: Bryozoan stable isotope survey from the cool-water Lacepede Shelf, Southern Australia. In: James, N. P.; Clarke, J. A. D. ed. Cool-water carbonates. SEPM Special Publication 56: 93-106.

Brey, T.; Gerdes, D.; Gutt, J.; MacKensen, A.; Starmans, A. 1999: Growth and age of the Antarctic bryozoan Cellaria incula on the Weddell Sea Shelf. Antarctic Science 11: 408-414.

Corfield, R. M. 1995: An introduction to the techniques, limitations and landmarks of carbonate oxygen isotope palaeothermometry. In: Bosence, D. W. J.; Allison, P. A. ed. Marine palaeoenvironmental analysis from fossils. Geological Society Special Publication 83: 27-43.

Crowley, S. F.; Taylor, P. D. 2000: Stable isotope composition of modern bryozoan skeletal carbonate from the Otago Shelf, New Zealand. New Zealand Journal of Marine and Freshwater Research 34: 331-351.

Forester, R. M.; Sandberg, P. A.; Anderson, T. F. 1973: Isotopic variability of cheilostome bryozoan skeletons. In: Larwood, G. P. ed. Living and fossil Bryozoa: recent advances in research. Academic Press. Pp. 79-94.

Goodwin, D. H.; Flessa, K. W.; Schöne, B. R.; Dettman, D. L. 2001: Cross-calibration of daily growth increments, stable isotope variation, and temperature in the Gulf of California bivalve mollusk Chione cortezi: implications for paleoenvironmental analysis. Palaios 16: 387-398.

Hageman, S. J. 1998: Bryozoan colonial growth-forms as paleoenvironmental indicators: evaluation of methodology. Palaios 12: 405-419.

James, N. P. 1997: The cool-water carbonate depositional realm. In: James, N. P.; Clarke, J. A. D. ed. Cool-water carbonates. SEPM Special Publication 56: 1-20.

James, N. P.; Bone, Y. 1989: Petrogenesis of Cenozoic, temperate water calcarenites, south Australia: a model for meteoric/ shallow burial diagenesis of shallow water calcite sediments. Journal of Sedimentary Petrology 59: 191-203.

James, N. P.; Bone, Y. 1991: Origin of a cool-water Oligo-Miocene deep-shelf limestone, Eucla Platform, southern Australia. Sedimentology 60: 323-341.

James, N. P.; Bone, Y. 1994: Paleoecology of cool-water, subtidal cycles in Mid-Cenozoic limestones, Eucla platform, southern Australia. Palaios 9: 457-477.

Kim, S-T.; O’Neil, J. R. 1997: Equilibrium and nonequilibrium oxygen isotope effects in synthetic carbonates. Geochimica et Cosmochimica Acta 61: 3461-3475.

Kroopnick, P. 1974: Correlations between ${ }^{13} \mathrm{C}$ and total $\mathrm{CO}_{2}$ in surface waters and atmospheric $\mathrm{CO}_{2}$. Earth and Planetary Science Letters 22: 397-403.

Machiyama, H.; Yamada, T.; Kaneko, N.; Iryu, Y.; Odawara, K.; Asami, R.; Matsuda, H.; Mawatari, S. F.; Bone, Y.; James, N. P. 2003: Carbon and oxygen isotopes of cool-water bryozoans from the Great Australian Bight, and their paleoenvironmental significance. In: Hine, A. C.; Feary, D. C.; Malone, M. J. ed. Proceedings of the Ocean Drilling Programme, Scientific Results 182 [online]. <http://wwwodp.tamu.edu/publications/182_SR/007/007.htm>

Nelson, C. S. 1978: Temperate shelf carbonate sediments in the Cenozoic of New Zealand. Sedimentology 25: 737-771.

Nelson, C. S.; Smith, A. M. 1996: Stable oxygen and carbon isotope compositional fields for skeletal and diagenetic components in New Zealand Cenozoic nontropical carbonate sediments and limestones: a synthesis and review. New Zealand Journal of Geology and Geophysics 39: 93-107. 
Nelson, C. S.; Keane, S. L.; Head, P. S. 1988a: Non-tropical carbonate deposits on the modern New Zealand shelf Sedimentary Geology 60: 71-94.

Nelson, C. S.; Hyden, F. M.; Keane, S. L.; Leask, W. L.; Gordon, D. P. 1988b: Application of bryozoan zoarial growth-form studies in facies analysis of non-tropical carbonate deposits in New Zealand. Sedimentary Geology 60: 301-322.

Nelson, W. A.; Gordon, D. P. 1997: Assessing New Zealand's marine biological diversity - a challenge for policy makers and systematists. New Zealand Science Review 54: 58-66.

Pätzold, J.; Ristedt, H.; Wefer, G. 1987: Rate of growth and longevity of a large colony of Pentapora foliacea (Bryozoa) recorded in their oxygen isotope profiles. Marine Biology 96: 535-538.

Rahimpour-Bonab, H; Bone, Y; Moussavi-Harami, R. 1997a: Stable isotope aspects of modern molluscs, brachiopods, and marine cements from cool-water carbonates, Lacepede Shelf, South Australia. Geochemica et Cosmochemica Acta 61: 207-218

Rahimpour-Bonab, H.; Bone, Y.; Moussavi-Harami, R.; Turnbull, K. 1997b: Geochemical comparison of modern cool-water calcareous biota, Lacepede Shelf, South Australia, with their tropical counterparts. In: James, N. P.; Clarke, J. A. D. ed. Cool-water carbonates. SEPM Special Publication 56: 77-91.

Rao, C. P. 1996: Oxygen and carbon isotope composition of skeletons from temperate shelf carbonates, eastern Tasmania, Australia. Carbonates and Evaporites 11: 169-181.

Rao, C. P.; Green, D. C. 1983: Oxygen- and carbon-isotope composition of cold shallow-marine carbonates of Tasmania, Australia. Marine Geology 53: 117-129.

Rao, C. P.; Jayawardane, M. P. J. 1994: Major minerals, elemental and isotopic composition in modern temperate shelf carbonates, Eastern Tasmania, Australia: implications for the occurrence of extensive ancient non-tropical carbonates. Palaeogeography, Palaeoclimatology, Palaeoecology 197: 49-63.

Rao, C. P.; Nelson, C. S. 1992: Oxygen and carbon isotope fields for temperate shelf carbonates from Tasmania and New Zealand. Marine Geology 103: 273-286.

Romanek, C. S.; Grossman, E. T.; Morse, J. W. 1992: Carbon isotope fractionation in synthetic aragonite and calcite: effects of temperature and precipitation rate. Geochimica et Cosmochimica Acta 56: 419-430.
Shackleton, N. J. 1965: The high-precision isotopic analysis of oxygen and carbon in $\mathrm{CO}_{2}$. Journal of Scientific Instruments 42: 689-692.

Smith, A. M. 1992: Aspects of the sedimentology of New Zealand bryozoans and mixed carbonate-clastic deposits: a contribution to the temperate shelf carbonate model. Unpublished DPhil thesis, Earth Sciences, University of Waikato, Hamilton, New Zealand. 459 p.

Smith, A. M. 1995: Palaeoenvironmental interpretation using bryozoans: a review. In: Bosence, D. W. J.; Allison, P. A. ed. Marine palaeoenvironmental analysis from fossils. Geological Society Special Publication 83: 231-243.

Smith, A. M.; Key, M. M. Jr 2004: A detailed stable isotope record in a single bryozoan skeleton: controls, variation, and a record of climate change. Quaternary Research 61(2): 123-133.

Smith, A. M.; Nelson, C. S. 1993: Mineralogical, carbonate geochemical, and diagenetic data for modern New Zealand bryozoans. Department of Earth Sciences, University of Waikato, Occasional Report 17. $71 \mathrm{p}$.

Smith, A. M.; Nelson, C. S.; Spencer, H. G. 1998: Skeletal mineralogy of New Zealand bryozoans. Marine Geology 151: $27-46$.

Smith, A. M.; Stewart, B.; Key, M. M. Jr; Jamet, C. M. 2001: Growth and carbonate production by Adeonellopsis (Bryozoa: Cheilostomata) in Doubtful Sound, New Zealand. Palaeogeography, Palaeoclimatology, Palaeoecology 175: 201-210.

Tarutani, T.; Clayton, R. N.; Mayeda, T. 1969: The effects of polymorphism and magnesium substitution on oxygen isotope fractionation between calcium carbonate and water. Geochimica et Cosmochimica Acta 33: 987-996.

Taviani, M.; Reid, D. E.; Anderson, J. B. 1993: Skeletal and isotopic composition and paleoclimatic significance of late Pleistocene carbonates, Ross Sea, Antarctica. Journal of Sedimentary Petrology 63: 84-90.

Weber J. N.; Raup, D. M. 1966: Fractionation of the stable isotopes of carbon and oxygen in marine calcareous organisms - the Echinoidea. Part I. Variation of ${ }^{13} \mathrm{C}$ and ${ }^{18} \mathrm{O}$ content with individuals. Geochimica et Cosmochimica Acta 30: 681-703.

Wurster, C. M.; Patterson, W. P.; Cheatham, M. M. 1999: Advances in micromilling techniques: a new apparatus for acquiring high-resolution oxygen and carbon stable isotope values and major/minor elemental ratios from accretionary carbonate. Computers \& Geosciences 25: 1159-1166. 
Appendix 1 Stable isotope data from Table 1 organised according to sub-categories. Abbreviations as for Table 1.

\begin{tabular}{|c|c|c|c|c|c|c|c|c|}
\hline & \multicolumn{2}{|c|}{ Number of } & \multicolumn{3}{|c|}{$\delta^{18} \mathrm{O}$} & \multicolumn{3}{|c|}{$\delta^{13} \mathrm{C}$} \\
\hline & specimens & $\overline{\text { species }}$ & Min. & Max. & $\overline{\text { Mean }}$ & Min. & Max. & Mean \\
\hline \multicolumn{9}{|l|}{ Mineralogy } \\
\hline $\mathrm{A} /(\mathrm{IMC})$ & 11 & 2 & 0.89 & 2.75 & 1.89 & 2.18 & 2.81 & 2.54 \\
\hline IMC & 25 & 9 & -1.35 & 1.97 & 0.73 & -3.08 & 2.15 & 0.66 \\
\hline $\mathrm{IMC} /(\mathrm{A})$ & 13 & 5 & -0.47 & 2.26 & 0.88 & -1.08 & 2.01 & 0.61 \\
\hline $\mathrm{IMC} / \mathrm{A}$ & 8 & 4 & -0.46 & 2.16 & 0.77 & 0.66 & 1.68 & 1.24 \\
\hline LMC & 24 & 7 & -0.80 & 1.97 & 0.60 & -4.50 & 1.62 & 0.65 \\
\hline $\mathrm{LMC} /(\mathrm{A})$ & 14 & 1 & 0.16 & 1.93 & 0.98 & -0.74 & 1.40 & 0.77 \\
\hline LMC/IMC & 8 & 2 & 0.40 & 2.37 & 1.37 & -0.08 & 1.66 & 1.24 \\
\hline \multicolumn{9}{|l|}{ Taxon } \\
\hline CY ho & 6 & 1 & 0.60 & 1.97 & 1.39 & 1.38 & 1.62 & 1.56 \\
\hline CY fa & 5 & 1 & -0.57 & 0.94 & 0.47 & -0.78 & 1.39 & 1.03 \\
\hline CY ci & 14 & 1 & 0.16 & 1.93 & 0.98 & -0.74 & 1.40 & 0.77 \\
\hline CY tu & 10 & 3 & -0.80 & 1.02 & 0.21 & -4.50 & 0.96 & -0.25 \\
\hline $\mathrm{CH}$ an & 28 & 9 & -1.35 & 2.75 & 1.01 & -3.08 & 2.81 & 0.85 \\
\hline $\mathrm{CH}$ as & 40 & 13 & -0.67 & 2.72 & 1.02 & -0.91 & 2.73 & 1.30 \\
\hline \multicolumn{9}{|c|}{ Growth form } \\
\hline $\mathrm{EN} \mathrm{ml}$ & 4 & 1 & 0.04 & 1.30 & 0.58 & 0.00 & 1.00 & 0.62 \\
\hline EN nd & 3 & 1 & 0.29 & 2.26 & 1.41 & 1.55 & 1.74 & 1.66 \\
\hline EN ul & 16 & 8 & -0.47 & 2.16 & 0.75 & -1.08 & 1.68 & 0.55 \\
\hline $\mathrm{EF}$ br & 9 & 2 & 0.07 & 2.37 & 1.28 & 1.00 & 1.66 & 1.37 \\
\hline EF lt & 3 & 3 & 0.57 & 1.48 & 0.90 & -0.91 & 0.95 & -0.17 \\
\hline EF rt & 3 & 1 & -1.35 & 0.39 & -0.22 & -3.08 & -1.48 & -2.12 \\
\hline ER de & 18 & 4 & -0.80 & 1.94 & 0.58 & -4.50 & 1.69 & 0.35 \\
\hline ER ra & 5 & 1 & -0.57 & 0.94 & 0.47 & 0.78 & 1.39 & 1.03 \\
\hline ER fe & 5 & 2 & -0.28 & 1.97 & 0.95 & 1.72 & 2.15 & 1.93 \\
\hline ER fo & 2 & 1 & 0.24 & 0.43 & 0.33 & 0.94 & 1.65 & 1.30 \\
\hline ER ro & 30 & 6 & -0.06 & 2.72 & 1.22 & -0.74 & 2.73 & 1.33 \\
\hline FL vg & 5 & 1 & 1.37 & 2.75 & 1.75 & 2.49 & 2.81 & 2.65 \\
\hline
\end{tabular}

